\title{
Assessing a Potential Conceive- Design-Implement-Operate Curricular Change in an Engineering Degree
}

\author{
Luiz Paulo Rodrigues Miranda \\ Department of Mechanical Engineering, School of Engineering, UFMG, Brazil. \\ E-mail: luizprmiranda@gmail.com.
}

\begin{abstract}
Resumo
As exigências da educação em Engenharia são muito amplas e exigem um conjunto de competências não só de conhecimento técnico, mas também a capacidade de liderar e inovar, e habilidades pessoais e interpessoais. Um quadro para avaliação de uma mudança curricular em potencial é necessário para orientar a análise com relação às partes interessadas e à legislação do país, a fim de desenvolver resultados de aprendizagem adequados. A abordagem Conceber-Design-ImplementarOperar (CDIO) foi escolhida para uma avaliação conduzida em um curso de engenharia mecânica no Brasil. O trabalho consistiu na aplicação de um levantamento com alunos e professores e uma revisão da literatura da legislação e de estudos que levantaram as competências necessárias e as habilidades para o engenheiro moderno. Os resultados mostram um grande potencial para um conjunto de habilidades CDIO em diplomas de engenharia no Brasil e revelam as demandas frequentes das partes interessadas antes de uma mudança curricular.
\end{abstract}

Palavras-chave: Acreditação, CDIO, Habilidades Pessoais e Interpessoais, Mudança Curricular.

\begin{abstract}
The requirements of the Engineering Education are nowadays very broad and demand a set of skills which demands not only technical knowledge but also the ability to lead and innovate and Personal and Interpersonal skills. A framework for the assessment of a potential Curricular Change is necessary to guide the analysis of the program with respect to the stakeholders and the legislation of the country, in order to develop appropriate learning outcomes. A Conceive-Design-ImplementOperate (CDIO) approach was chosen for an evaluation conducted in a Mechanical Engineering
\end{abstract}


Degree in Brazil. The work consisted in the application of a survey with students and professors and a literature review of the legislation and studies that raised the required competences and skills for the modern Engineer. The results show a great potential for a CDIO set of skills in Engineering Degrees in Brazil and reveal the frequent demands of stakeholders before a curricular change.

Keywords: Accreditation, CDIO, Curriculum Change, Personal and Interpersonal Skills.

\section{Resumen}

Los requisitos de la educación en ingeniería son muy amplios y exigen un conjunto de habilidades no solamente de conocimientos técnicos sino también la capacidad de liderar e innovar, y las habilidades Personales e Interpersonales. Un marco para la evaluación de un Cambio Curricular en potencial es necesario para guiar el análisis con respecto a las partes interesadas y a la legislación del país, a fin de desarrollar los resultados de aprendizaje apropiados. Se escogió un enfoque Concebir-Diseño-Implementar-Operar (CDIO) para una evaluación realizada en un curso de ingeniería mecánica en Brasil. El trabajo consistió en la aplicación de un levantamiento con estudiantes y profesores y una revisión de la literatura de la legislación y de estudios que reconocieron las competencias necesarias y las habilidades para el ingeniero moderno. Los resultados muestran un gran potencial para un conjunto de habilidades CDIO en títulos de ingeniería en Brasil y revelan las demandas frecuentes de las partes interesadas antes de un Cambio Curricular.

Palabras claves: Acreditación, CDIO, habilidades Personales e Interpersonales, Cambio Curricular. 


\section{Introduction}

Nowadays it is required that an Engineer has a broad and generalist instruction, able to create and innovate in a world and Society in constant change. "Graduating Engineers should be able to conceive-design-implement-operate complex value-added Engineering products, processes, and systems in a modern, team based environment" ${ }^{1}$. Students have to confront real Engineering problems and be competent in performing their activities, what includes both technical knowledge and Personal and Interpersonal skills.

The Conceive-Design-Implement-Operate approach (CDIO) is an educational methodology for Engineering, which places the modern Engineer instruction in the context of conception, modelling and design, implementation and operation of products, systems and processes. It seeks to "develop programs that are educationally effective and more exciting to students, attracting them to Engineering, retaining them in the program and in the profession"1.

A Conceive-Design-Implement-Operate approach (CDIO) was chosen as a practical model for curriculum and education context change because it is used worldwide with that application, with emphasis in the regularization of Engineering Degrees according to standards, and it is a broad compilation of good teaching and assessment methods. The methodology is now present in more than 80 Universities in the world.

The educational reform should be made in a way that "it reflects the point of view of all stakeholders: students, professors and Society". In this study, professors and students were inquired about a Conceive-Design-Implement-Operate context and Personal and Interpersonal skills development. The Society and industry, the remaining stakeholders, were assessed with the review of surveys and legislation. The focus is on the curriculum and the learning objectives of the degree, which once defined will lead to adequate assessment and teaching measures.

\section{Methods}

The first step in the study was a literature review of the legislation of Engineering Education in Brazil in order to evaluate the feasibility of a curricular change to a CDIO approach. The two most relevant documents were $\mathrm{w}^{2-4}$. All the required competences were aligned, when possible, with the first level of detail in the CDIO Syllabus ${ }^{5}$. This would assure that a CDIO approach is possible to be implemented according to the educational and professional laws in Brazil. The first analysis can verify if a CDIO approach can corroborate with the expected competences and other outcomes for the Engineer in the selected country.

Just verifying the requirements in law for the accreditation of an Engineering Degree in Brazil and adopting the CDIO context and development of personal and interpersonal skills in the formal instruction of the Engineer are not enough for a curriculum design. In order to a more detailed development of outcomes, two previous studies which surveyed the main stakeholders involved in Engineering Education (students, professors and industry), were combined in this paper to list the main professional, personal and interpersonal skills collected by these studies and compose the second level of detail in the CDIO Syllabus adapted to the Brazilian reality. These studies, carried out in São Paulo ${ }^{6}$ and Belo Horizonte ${ }^{7}$, both represent the reality in the southeast of the country and rank the most important skills for the modern Engineer. Defining the relevance of each topic provides valuable information to create the framework of these skills to be developed in a new curriculum.

An assessment of the actual presence of context of the life cycle of products, systems and processes in Engineering and personal and interpersonal skills development in the actual 
Mechanical Engineering program was conducted in the Universidade Federal of Minas Gerais (UFMG), in Belo Horizonte, Brazil, in the year of 2012. Two short and similar surveys were made with the form and spreadsheets tools from Google Driveß. One was sent to all students of the Mechanical Engineering bachelor Degree and the other was sent to the teaching staff of the Mechanical Engineering Department by email.

The survey consisted in 10 assertions in which the respondents should choose the level of agreement with it in a Likert scale numbered from 1 to 6 . A person who chooses " 1 " disagrees totally with the assertion presented and a person that chooses " 6 ' agrees totally with it. There were two sets of five questions, one assessing the context of conceiving, design, implementing and operation (CDIO context) and the other assessing the development of personal and interpersonal skills. They are the following assertions (A), from 1 to 5:

- A1: The Mechanical Engineer carries out activities [in the phases of conceiving, designing, implementing and operation of products, processes and systems regarding mechanical, electromechanical and thermal equipment, and its related services]/[which involve Personal and Interpersonal skills like flexibility, risk management, ethics, teamwork and communication].

- A2: The Engineering Education should [adopt the context of conception, design, implementing and operation of products and processes and systems]/[develop personal and interpersonal skills in the disciplines].

- A3: The [context of conceiving, design, implementing and operation of products, processes and systems]/[development of Personal and Interpersonal skills] is present in the Mechanical Engineering bachelor Degree in UFMG.

- A4: The [context of conceiving, design, implementing and operation of products, processes and systems]/[development of Personal and Interpersonal skills] was present in at least one of the disciplines I taught or studied.

- A5: I wish that the disciplines I study or teach were more inserted in [a context of conceiving, design, implementing and operation of products, processes and systems]/[the development of Personal and Interpersonal skills].

Both students and professors also had a field in the survey for typing remarks or comments about the assertions, the University, the CDIO context and the personal and interpersonal skills development, and for better expressions of their opinions. These were taken in account for the elaboration of the discussion section.

\section{Results}

The alignment of the Brazilian competences required by the Engineering Education legislation with the CDIO Syllabus is represented in Table 1. The competences in the table are general requirements for the Accreditation of an Engineering Degree in Brazil, according to ${ }^{2-4}$. The roman figures I., II., III. and IV. identify each one of the categories that comprise the first level of the CDIO Syllabus.

Of 50 professors in the department, 20 of them (40\%) responded to the survey. Figure 1 shows how many students answered the survey and in which semester they were currently studying. It is important to notice that, in Brazil, the Engineering Degree comprises of 10 semesters for full-time courses and 12 semesters for night-time courses. That means, the 11th and 12th respondents belong only to the night-time Mechanical Engineering Degree of the University. 
The results with the average level of agreement and standard deviation are represented in Table 2, along with the variation of agreement level between teaching staff and students.

The creation of learning outcomes expected in the personal and interpersonal skills, and also for the development of systems, products and processes is best conducted when the requirements of the stakeholders are clear and categorized. The second level of the CDIO Syllabus is an extensive list of skills and knowledge that can be adapted to the reality of the applied country's context. The skills ranked in 6,7 were placed in the categories of the Syllabus as shown in Tables 3 to 6. In Tables 3 and 6, the topics 2.3 (System Thinking) and 4.3 (Conceiving, Systems Engineering and Management) presented little demand by the stakeholders to be relevant in a Curricular Change and hence do not appear.

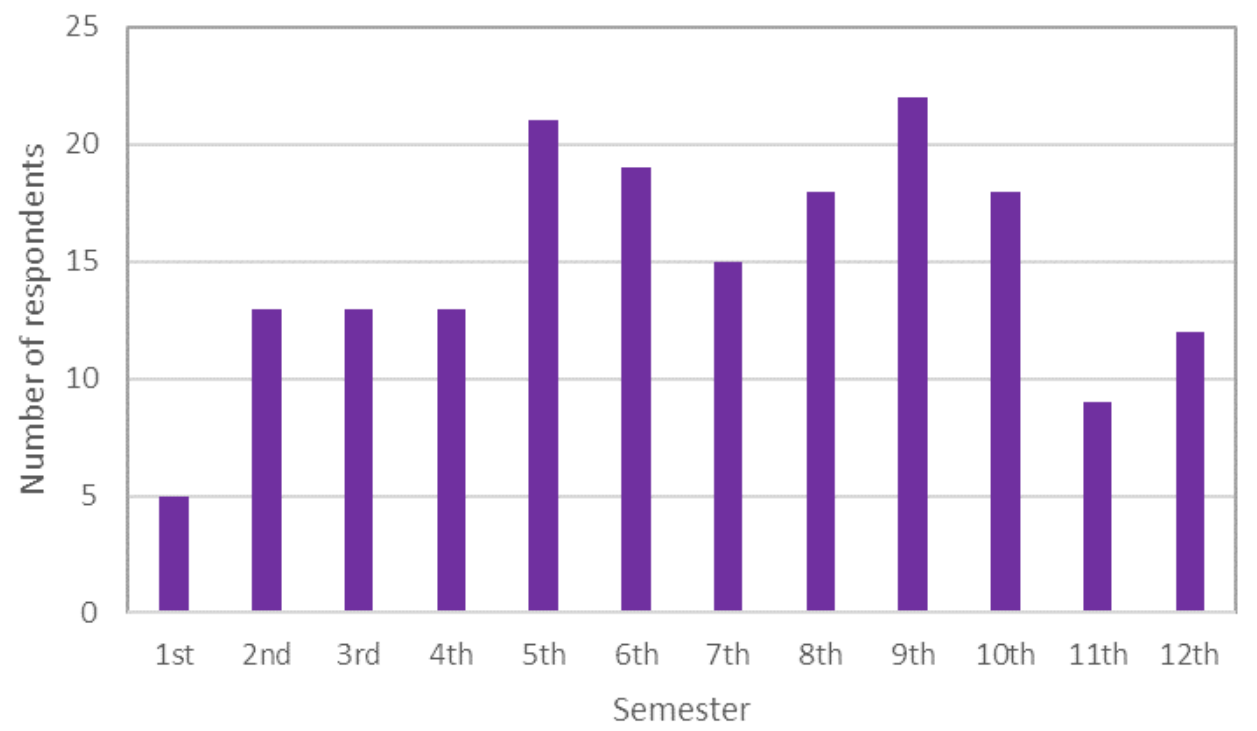

Figure 1: Number of students who responded the survey in each semester of degree

Table 1. Engineer's Competences Aligned With The First Level Of Detail In The CDIO Syllabus.

\begin{tabular}{|l|l|l|}
\hline $\begin{array}{l}\text { I. Technical know- } \\
\text { ledge and reasoning }\end{array}$ & $\begin{array}{l}\text { II. \& III. Personal, } \\
\text { Interpersonal and } \\
\text { Professional Skills } \\
\text { and Attributes }\end{array}$ & $\begin{array}{l}\text { IV. Conceiving, de- } \\
\text { signing, implemen- } \\
\text { ting, and operating } \\
\text { systems in the en- } \\
\text { terprise and socie- } \\
\text { tal context }\end{array}$ \\
\hline $\begin{array}{l}\text { Apply mathemati- } \\
\text { cal, scientific and } \\
\text { technological know- } \\
\text { ledge to Enginee- } \\
\text { ring; }\end{array}$ & $\begin{array}{l}\text { Communicate effi- } \\
\text { ciently in written, } \\
\text { oral and graphic } \\
\text { ways; }\end{array}$ & $\begin{array}{l}\text { Conceive, design } \\
\text { and analyze sys- } \\
\text { tems, products and } \\
\text { processes; }\end{array}$ \\
\hline
\end{tabular}




\begin{tabular}{|l|l|l|}
\hline $\begin{array}{l}\text { Design and lead ex- } \\
\text { periments and in- } \\
\text { terpret results; }\end{array}$ & $\begin{array}{l}\text { Work in multidisci- } \\
\text { plinary teams; }\end{array}$ & $\begin{array}{l}\text { Plan, supervise, } \\
\text { elaborate and } \\
\text { monitor projects } \\
\text { and services of } \\
\text { Engineering; }\end{array}$ \\
\hline $\begin{array}{l}\text { Identify, model and } \\
\text { solve Engineering } \\
\text { problems; }\end{array}$ & $\begin{array}{l}\text { Comprehend and } \\
\text { apply ethics and } \\
\text { professional res- } \\
\text { ponsibility; }\end{array}$ & $\begin{array}{l}\text { Monitor the ope- } \\
\text { ration and mainte- } \\
\text { nance of systems; }\end{array}$ \\
\hline $\begin{array}{l}\text { Develop and/or use } \\
\text { new tools and tech- } \\
\text { niques } \\
\text { permanent profes- } \\
\text { sional development; }\end{array}$ & $\begin{array}{l}\text { Evaluate critically } \\
\text { the operation and } \\
\text { maintenance of sys- } \\
\text { tems; }\end{array}$ \\
\hline & $\begin{array}{l}\text { Evaluate the im- } \\
\text { pact of activities of } \\
\text { Engineering in the } \\
\text { social and environ- } \\
\text { mental context; }\end{array}$ \\
\hline $\begin{array}{l}\text { Evaluate the eco- } \\
\text { nomical feasibility } \\
\text { of Engineering pro- } \\
\text { jects; }\end{array}$ \\
\hline
\end{tabular}

Table 2: Results of the survey in UFMG

\begin{tabular}{|c|l|l|c|c|}
\hline & & $\begin{array}{l}\text { Teaching } \\
\text { Staff }\end{array}$ & Students & Variation \\
\hline \multirow{4}{*}{ CDIO Context } & A1 & $5,70 \pm 0,47$ & $5,49 \pm 0,80$ & $-3,4 \%$ \\
\cline { 2 - 5 } & A2 & $5,35 \pm 0,87$ & $5,09 \pm 1,00$ & $-4,3 \%$ \\
\cline { 2 - 5 } & A3 & $3,95 \pm 1,14$ & $3,66 \pm 1,24$ & $-4,7 \%$ \\
\cline { 2 - 5 } & A4 & $5,00 \pm 1,33$ & $4,35 \pm 1,50$ & $-10,8 \%$ \\
\cline { 2 - 5 } & A5 & $3,94 \pm 2,17$ & $5,17 \pm 1,05$ & $20,5 \%$ \\
\hline \multirow{4}{*}{$\begin{array}{c}\text { Personal \& Inter- } \\
\text { personal Skills }\end{array}$} & A1 & $5,4 \pm 0,94$ & $5,59 \pm 0,79$ & $3,3 \%$ \\
\cline { 2 - 5 } & A2 & $4,95 \pm 1,19$ & $4,7 \pm 1,45$ & $-4,1 \%$ \\
\cline { 2 - 5 } & A3 & $2,85 \pm 1,18$ & $3,05 \pm 1,25$ & $3,4 \%$ \\
\cline { 2 - 5 } & A4 & $4,40 \pm 1,42$ & $3,35 \pm 1,31$ & $-17,4 \%$ \\
\hline
\end{tabular}

Table 3. Engineer's competences aligned with the second level of detail in the CDIO Syllabus (Part I).

\begin{tabular}{|l|}
\hline 1. Technical Knowledge and Reasoning \\
\hline Computer and information technology use ${ }^{6}$ \\
\hline Standards and procedures knowledge $^{6}$ \\
\hline Quality control $^{6}$ \\
\hline
\end{tabular}




\begin{tabular}{|l|}
\hline Fundamentals of science $^{6}$ \\
\hline Fundamentals of engineering and its applications \\
\hline Use of basic tools of information technology \\
\hline General knowlegde in engineering \\
\hline Use of specific softwares in engineering $^{7}$ \\
\hline Inspection and labeling standards $^{6}$ \\
\hline Technical procedures $^{6}$ \\
\hline Probability and statistics $^{6}$ \\
\hline
\end{tabular}

Table 4. Engineer's competences aligned with the second level of detail in the CDIO Syllabus (Part II).

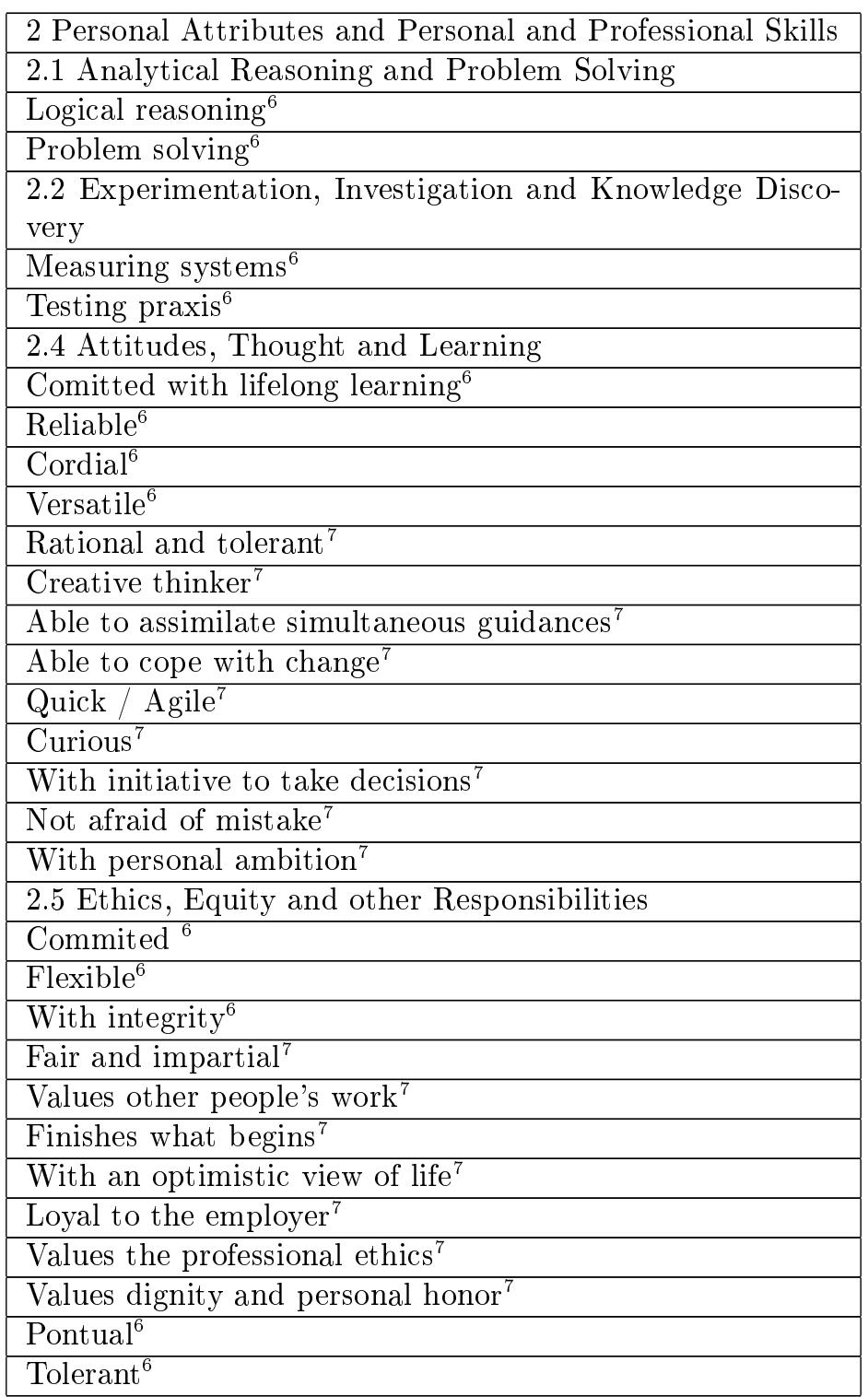


Table 5. Engineer's competences aligned with the second level of detail in the CDIO Syllabus (Part III).

\begin{tabular}{|c|}
\hline 3 Interpersonal Skills: Teamwork and Communication \\
\hline 3.1 Teamwork \\
\hline Organization, Leadership and Management $^{6}$ \\
\hline Able to work in teams ${ }^{7}$ \\
\hline With ability to lead employees ${ }^{7}$ \\
\hline Able to say to subordinate what he/she wants ${ }^{7}$ \\
\hline Objective in assigning goals ${ }^{7}$ \\
\hline Values other people's work ${ }^{7}$ \\
\hline 3.2 Communication \\
\hline Communication $^{6}$ \\
\hline Professional and technical language $^{6}$ \\
\hline Able to express in an organized and clear manner ${ }^{7}$ \\
\hline Able to write well ${ }^{7}$ \\
\hline 3.3 Communication in foreign languages \\
\hline Write in another language ${ }^{6}$ \\
\hline Speak in another language ${ }^{6}$ \\
\hline With good knowledge of english ${ }^{7}$ \\
\hline
\end{tabular}

Table 6. Engineer's competences aligned with the second level of detail in the CDIO Syllabus (Part IV).

4 Conceiving, Design, Implementing and Operating Systems in the Enterprise, Societal and Environmental Context - The Innovation Process

4.1 External, Societal and Environmental Context

Ethics Codes ${ }^{6}$

With general and broad culture ${ }^{7}$

Concerned about the environment ${ }^{7}$

Environmental Responsibility ${ }^{6}$

4.2 Enterprise and Business Context

International Competitivity $^{6}$

Guarantees $^{6}$

Organization, Leadership and Management ${ }^{6}$

Costs Knowledge ${ }^{7}$

Good Negotiatior $^{7}$

Able to make chronograms ${ }^{7}$

With a good vision of the client-supplier role $^{7}$

Able to plan ${ }^{7}$

With vision of the market's needs ${ }^{7}$

4.4 Designing

With ability to reduce $\operatorname{costs}^{7}$

4.5 Implementing

With a global view of the production ${ }^{7}$ 
ISSN: 2358-1271. Int. J. of Alive Eng. Educ. (IJAEEdu). (Online). Goiânia, v. 4, n. 1, p. 17-28, jan./june 2017.25

\begin{tabular}{|l|}
\hline With ability to reduce costs \\
\hline Concerned about the security and healh in the workplace \\
\hline 4.6 Operation \\
\hline With a global view of the production \\
\end{tabular}

\section{Discussion}

Table 1 shows that all the requirements of the ministry of education from Brazil regarding the competences of the Engineer can be classified into the main categories of the CDIO Syllabus. This was expected, due to the broad and descriptive nature of the list of competences which has been adapted in dozens of countries around the world. The legislation in Brazil is aware of the actual context of work of the modern Engineer. Those results, though, are still not sufficient for the design of learning outcomes, because they do not communicate the skills necessary to perform the professional activities. These can be detailed with the analysis of the second level of the CDIO Syllabus.

The results in Table 2 show a great level of agreement from both professors and students with respect to the presence of the CDIO context and the Personal and Interpersonal skills in the profession of the Engineer. They also agree, in a lower but still high level, that the education of the Engineer is responsible for developing and presenting this context and skills.

In the assertion A3 the respondents reported a middle level of agreement with respect to the presence of the context and the Personal and Interpersonal skills in the Mechanical Engineering Degree, with a lower average for the latter. When asked about their experience with disciplines they studied or taught, which the case of assertion A4, this level increases. Another data which demands attention is the higher relative disparity between the levels of agreement in A4 for students and professors. Some hypothesis can be made to explain these opinions. The assertion A4 did not ask for an average grade for the presence of the context or skills, but it relies on the experience of at least one discipline of the respondent. The student or professor recalls his or her best experiences with this discipline, especially the teaching staff, who can be biased to evaluate better their own performance in teaching these contents. Another likely explanation is that professors and students have dissimilar opinions concerning the contents to be taught in order to develop the skills. The variability of few disciplines studied or taught by the respondents reflects on the discrepancy of values. In a Curriculum Design, the content should be clear in the communication of learning objectives, emphasizing the use of observable actions ${ }^{8}$, in order to diminish these issues on assessing and classifying the expectations related to the development of content and skills. It is important to be aware of bias and variability due to small samples in further studies.

Assertion A5 presents high inequality of agreement between teachers and students. Also, this one shows the highest variation of data among the teaching staff. The difference between the groups can be explained using the results from the previous assertions. Since 
both groups believe that the topics should be handled in the Engineering Education, and professors believe they already cover them but students don't, it is natural that students demand more presence of these contents. Some professors actually agree very little that they should cover more content on the CDIO context and Personal and Interpersonal skills. A detailed graphic representation of the answers to assertion A5 for the teaching staff is present in Figure 2.

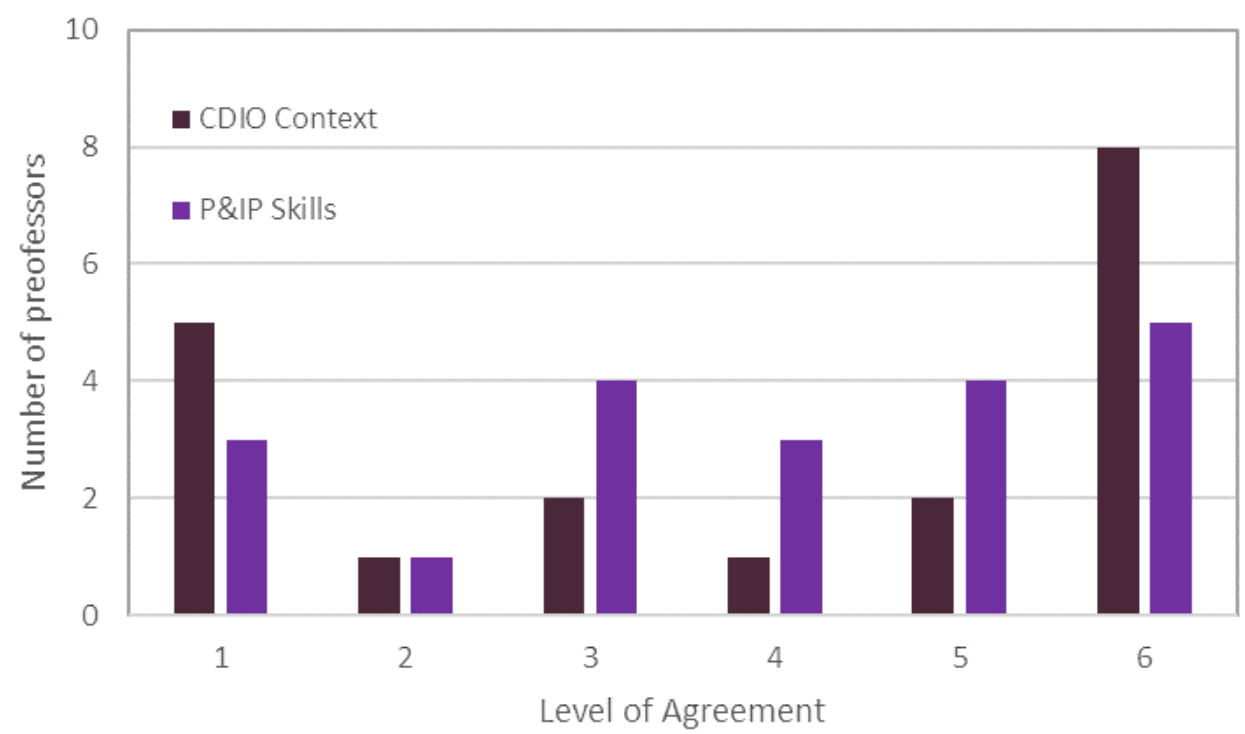

Figure 2. Number of respondents in the teaching staff for each level of agreement with the assertion A4.

The high standard deviation for A5 is the result of the high variability of results in the Personal and Interpersonal skills and the great number of extreme values " 1 " and "6" for the CDIO context. Some professors may believe that they already cover enough content of these subjects and do not need to teach more of it, especially for the context. The variability could be explained as well taking in account that the number of respondents is relatively low. Professors actually could be teaching in a context of conceiving, designing, implementing and operating systems with the development of Personal and Interpersonal skills. This is made clear when good communication of learning objectives and appropriate assessment are performed. The successes of the instruction on these subjects could be peer reviewed and implemented by the entire staff in a Curriculum Design.

The overall results regarding assertions A4 and A5 say that students have a middle agreement over their experience with the development of Personal and Interpersonal skills and perceive a higher presence of the context of systems, products and processes development. Despite this fact, they demand more training in the CDIO context than in the 
ISSN: 2358-1271. Int. J. of Alive Eng. Educ. (IJAEEdu). (Online). Goiânia, v. 4, n. 1, p. 17-28, jan./june 2017.

Personal and Interpersonal skills. This should be expected, considering the greater interest in practical experience desired by the students in their remarks at the end of the survey. They want to participate in the solution of real problems, have better use of technology in computer and machinery and acquire more training in leading Engineering projects and enterprises.

Some professors and students expressed concerns with Personal and Interpersonal skills development in the Mechanical Engineering bachelor Degree. This could have supported the pattern of lower agreement in assertion A5 for these skills. The majority of comments discredits the usual training of these skills in UFMG and other Universities in Brazil. Usually, new disciplines like entrepreneurship and ethics are created, instead of including these subjects in already existent disciplines and other activities ${ }^{9}$. The CDIO approach suggests new methods of teaching and assessing these skills and adapting the current program, instead of creating new curricular units ${ }^{1}$.

Refining the skills relevant to the activities of the Engineer could be made filtering the extensive list of skills from the second level of the CDIO Syllabus with applied research with the stakeholders in a particular context. The two surveys related in Tables 3, 4, 5 and 6 provided reliable information for the elaboration of learning outcomes. For instance, the topics 2.3 (System Thinking) and 4.3 (Conceiving, Systems Engineering and Management) presented little demand by the stakeholders to be relevant in a Curricular Change and hence do not appear in the table. This does not mean that these topics should not be covered at all or they are not important in the formation of the Engineer.

\section{Final Considerations}

The obtained list of skills is primary information for the design of curriculum and learning outcomes that supports additional discussions and priorities by the faculty in a Curricular Change program. The analysis of the actual program should be supported by a framework to identify whether the curricular units do approach Conceive-Design-Implement-Operate principles, to address misinterpretations of evaluations and to build a concise curriculum.

This study also supports the idea that learning objectives should take in account demands from different stakeholders, like industry, Society, the government and the students along with the teaching staff in order to address the concerns of modern engineering problems.

\section{Reference}

1. E. F. CRAWLEY, J. MALMQVIST, S. ÖSTLUND, D. R. BRODEUR. Rethinking Engineering Education. Springer Science Business Media, LLC, 2007.

2. BRASIL. Resolução CNE/CES $11 / 2002,11^{\text {th }}$ March 2002. Diário Oficial da União, CNE, Seção 1, p. 32. April 2002.

3. BRASIL. Resolução 1.010, $22^{\text {th }}$ August 2005. Diário Oficial da União, Confea. Brasília, Brazil. $22^{\text {th }}$ August 2005 .

4. BRASÍLIA (ESTADO). Decisão PL 1139/2012. August 2012. Lex: Confea. Terceira Sessão Plenária Extraordinária. Brasália, Brazil. 
5. E. F. CRAWLEY, W. A. LUCAS, J. MALQViST, D. R. BRODEU. The CDIO Syllabus v2.0: An Updated Statement of Goals for Engineering Education. In INTERNATIONAL CDIO CONFERENCE, $7^{\text {th }}$., 2011, Technical University of Denmark, Copenhagen. June 2011.

6. N. M. VERTICCHIO. Análise comparativa das habilidades e competências necessárias para o engenheiro na visão da indústria, dos discentes e dos docentes. Belo Horizonte, Brazil. August 2006.

7. RBF Sistemas e Métodos de Informação. O engenheiro dos novos tempos. São Paulo, Mimeo, March 1998.

8. R. M. FELDER, R. BRENT. The ABC's of Engineering Education: ABET, Bloom's Taxonomy, Cooperative Learning and so on: American Society for Engineering Education Annual Conference \& Exposition,2004.

9. F. O. SIMON. Habilidades e Competências em Engenharia: Criação e validação de um instrumento.2004. Dissertação - UNICAMP , Campinas, SP, Brazil. 2004. 